\title{
ENKELE FACETTEN VAN DE ECONOMISCHE ONTWIKKELING VAN SURINAME
}

Terugblikkend op de economische ontwikkeling, die zich in Suriname in de periode van 1954-64 heeft voltrokken, kan men in ieder geval de conclusie trekken dat de bedrijvigheid gedurende deze periode niet alleen belangrijk groter is geweest dan die in de voorafgaande decennia, doch dat tevens tot op zekere hoogte een basis werd gelegd voor de noodzakelijke opvoering van de nationale productie. Geeft dit aanleiding tot tevredenheid en vertrouwen met betrekking tot de aanwezige mogelijkheden voor een verdere versnelde ontwikkeling, het betekent echter nog niet - zoals nader zal blijken - dat enkele belangrijke vraagstukken, waarmede Suriname wordt geconfronteerd, tot definitieve en bevredigende oplossing zijn gebracht.

In de eerste plaats dient er op te worden gewezen dat de bereikte economische vooruitgang voor een zeer belangrijk deel gedragen werd door activiteiten, gefinancierd uit ontwikkelingsgelden verstrekt door Nederland en in mindere mate door de Verenigde Staten van Amerika en enkele internationale organen, alsmede door de investeringen van enkele grote, reeds in Suriname werkzame particuliere ondernemingen zoals de Suriname Aluminium Cy (Suralco), Bruynzeel Suriname Hout Mij en de Billiton Mij Suriname.

Ondanks de inspanning, die Suriname zich daartoe getroost heeft, moest de eigen bijdrage in de financiering van de ontwikkelingsactiviteiten in absolute zin van vrij bescheiden omvang blijven. Indien in aanmerking wordt genomen dat Suriname een land in ontwikkeling is met een geringe bevolking, een acuut werkgelegenheidsvraagstuk en een nog niet op peil gekomen productieapparaat, kon redelijkerwijs ook niet anders verwacht worden.

Voor velen is het een teleurstelling geweest dat de investeringsactiviteiten van de particuliere sector, zowel die van binnenlandse als buitenlandse oorsprong, belangrijk ten achter zijn gebleven bij de verwachtingen die daaromtrent gekoesterd 
werden. Of deze teleurstelling al dan niet gerechtvaardigd is, is een moeilijk te beantwoorden vraag. Voor een juiste oordeelvorming over dit probleem zijn niet alleen nodig exacte cijfers over de particuliere investeringsactiviteit, waarover momenteel niet kan worden beschikt, doch tevens een nuchter en objectief inzicht in de factoren, die het investeringsklimaat bepalen. Op dit aspect zal elders in dit artikel nog in het kort worden teruggekomen.

Wat de particuliere investeringsactiviteiten betreft, hierover zijn slechts fragmentarische gegevens bekend, die overigens wel enige indicatie opleveren. Zo werden ten behoeve van de missie Prof. P. Lieftinck in april 1959, op instigatie van de Vereniging Surinaams Bedrijfsleven, door enkele accountantskantoren gegevens verzameld over de totale investeringen, die in de periode $1954 \mathrm{t} / \mathrm{m}$ I958 in de particuliere sector hebben plaats gevonden. $\mathrm{Bij}$ dit onderzoek is er naar gestreefd cijfermateriaal te verzamelen over alle bedrijven met een investering van meer dan Sf. 50.000 en een aantal werknemers van meer dan ro man. Blijkens dit onderzoek bedroegen de bruto-investeringen door deze bedrijven in de jaren $1954 \mathrm{t} / \mathrm{m}$ I958 in totaal Sf. 87,6 miljoen, waarvan rond Sf. 38,5 miljoen $(44 \%)$ in de mijnbouwkundige sector, Sf. I7.5 miljoen $(20 \%)$ in de agrarische sector en bijna Sf.ro miljoen $(\mathrm{II} \%)$ in de industriële sector. Onder de gegeven omstandigheden kan dit cijfer niet onbevredigend worden genoemd, vooral indien in aanmerking wordt genomen dat de overheidsinvesteringen in die periode rond Sf. 45 miljoen bedroegen en het leeuwendeel van de omvangrijke Brokopondo-investeringen door Suralco, en van belangrijke uitbreidingsinvesteringen door enkele andere grote ondernemingen eerst na $195^{8}$ plaatsvonden.

Wel kan gesteld worden dat het particuliere investeringsvolume bij lange na niet toereikend was om te kunnen voorzien in de bestaande behoefte aan additionele werkgelegenheid. welke overigens zeer groot is. Evenzeer kan naar voren worden gebracht dat de ontwikkelingsactiviteiten, gefinancierd in het kader van de buitenlandse gouvernementele en semi-gouvernementele hulpverlening, vermoedelijk een te grote bijdrage hebben geleverd in verhouding tot de verhoogde economische bedrijvigheid en grotere welvaart, die bereikt werd.

De belangrijkste plaats bij deze vorm van hulpverlening wordt ongetwijfeld ingenomen door het Tienjarenplan, dat een drieledig doel heeft n.l. een regelmatige verhoging van het reëel inkomen van de bevolking, verbetering van de betalingsbalans en ver- 
breding van de economische basis van het land, waardoor ook de werkgelegenheid zou worden verruimd. Primair werd het accent gelegd op investeringen, welke gericht waren op een verbetering van de infrastructuur. Eerst sedert I 963 werd meer aandacht geschonken aan investeringen in de direct-productieve sectoren.

Volgens de oorspronkelijke opzet was voor dit plan Sf. I27 miljoen uitgetrokken. Hiervan zou één derde deel door Suriname zelf worden opgebracht, terwijl van het resterend gedeelte de helft door Nederland als lening werd verstrekt en de helft als schenking. In I960 werd dit plan uitgebreid met het $\mathrm{zg}$. Aanvullend Opbouwplan ad Sf. 80 miljoen, waarin door Nederland op dezelfde voorwaarden als voor het Tienjarenplan gelden, wordt deelgenomen, terwijl in 1964 nog een suppletie plaats vond met Sf. 6,25 miljoen. Het totale geldsbedrag waarover in het kader van het Tienjarenplan annex het Aanvullend Opbouwplan beschikt kan worden, bedraagt derhalve ruim Sf. 2I3 miljoen, waarvan tot en met ultimo I964 naar schatting reeds Sf. I68 miljoen besteed is. Het resterend deel van de fondsen zal in de jaren 1965 en 1966 verbruikt worden.

Toen Suriname zich in 1962 voor ernstige liquiditeitsmoeilijkheden geplaatst zag, werd met Nederland overeengekomen dat de ontwikkelingshulp, die Suriname als geassocieerd lid van de E.E.G. uit het ontwikkelingsfonds van deze Gemeenschap zou verkrijgen, met ingang van 1963 in de plaats zou treden van Suriname's bijdrage aan de financiering van het Tienjarenplan.

Behalve de Tienjarenplan-hulp ontving Suriname ook nog uit andere bronnen bijstand en financieringssteun, die echter van geringer omvang waren en in sommige gevallen incidenteel van aard. In dit verband dient naar volgorde in de eerste plaats genoemd te worden de hulpverlening in het kader van de Amerikaanse Technische Bijstand aan Suriname, waarbij het accent lag op de beschikbaarstelling van deskundigen, het verrichten van onderzoekingen en niet zo zeer op de financiering van projecten. Deze Amerikaanse bijstand werd in 1963 beëindigd doch het is niet uitgesloten dat zij in de toekomst in een andere vorm zal worden hernieuwd.

Voor enkele projecten werd voorts gedeeltelijke financieringshulp verkregen van het United Nations Special Fund. Van grotere importantie is evenwel de hulp, die Suriname krachtens het geassocieerd lidmaatschap kan verkrijgen uit het Ontwikkelingsfonds van de E.E.G. Voor de vijfjarige periode I963 tot en 
met 1967 kan gerekend worden op financiële steun tot een bedrag van ten minste U.S. \$29 miljoen. Het totale aantal bij de E.E.G. ter financiering ingediende projecten bedraagt thans $\mathrm{I} 7$. Hiervan zijn reeds 6 projecten goedgekeurd, met de uitvoering waarvan spoedig een begin zal worden gemaakt.

Daar het streven van de huidige Surinaamse Regering er op gericht is bij het aanboren van nieuwe financieringsbronnen het spreidingsbeginsel toe te passen, zodat men niet in belangrijke mate op financiële hulp van Nederland in het bijzonder blijft aangewezen, worden de ogen nu sedert enige tijd ook gericht op de West-Duitse Bondsrepubliek. Begin october I964 tekende Suriname een overeenkomst met het Salzgitter-concern, dat tegen betaling van een honorarium van Sf. 660.000 voorstudies zal verrichten over een zevental door Suriname ingediende projecten. Mochten deze projecten economisch bezien uitvoerbaar zijn, dan zal Salzgitter zich beijveren voor het aantrekken van financieringsmiddelen voor deze projecten, welke van grootse allure zijn en op vele honderden miljoenen guldens geraamd worden.

In de afgelopen tienjarige periode stond ook de landsbegroting in het teken van expansie. Een expansie, die echter op den duur aanleiding gaf tot het optreden van vrij ernstige spanningen in de financiële en monetaire sector.

Zelfs bij een vluchtige beschouwing van het verloop van de totale dienst van de begrotingen kan aanstonds de conclusie worden getrokken dat in het bijzonder het uitgavenpeil snel steeg nl. van Sf. 39,6 miljoen in I954 (realisatiecijfer) tot Sf. 86,6 miljoen in I960 (voorlopig cijfer) en Sf. IIo,3 miljoen in 1965 (cijfer ontwerpbegroting). Hiertegenover stond echter geen adequaat accrès van de inkomsten, zoals door de volgende cijfers wordt geillustreerd: I954 Sf. 36,8 miljoen, I96o Sf. 76,5 miljoen en 1965 Sf. I10,2 miljoen (inclusief Sf. I2,92 miljoen van Nederlandse overbruggingslening).

Het gevolg van de toenemende discrepantie tussen uitgaven en inkomsten was dat de allengs groter wordende begrotingstekorten (totale dienst) op een gegeven ogenblik niet langer konden worden opgevangen door nog aanwezige financiële reserves. Door het verder opvoeren van het uitgavenpeil en het uitblijven van bezuinigings- en inkomstenverhogende maatregelen, vond ten slotte een zodanige accumulatie van tekorten plaats dat Suriname in 1962 met ernstige liquiditeitsmoeilijkheden geconfronteerd werd. 
Het gevaar van een financieel en monetair débâcle - want ook de afvloeiing van deviezen had ernstige vormen aangenomen - kon slechts bezworen worden door het treffen van een aantal monetaire maatregelen en door budgetaire overbruggingshulp, die door Nederland werd verleend. In feite kwam deze hulp echter ten laste van de Tienjarenplan-middelen. Voorts werd, zoals reeds vermeld, de druk op de kapitaaldienst van de Surinaamse begroting verlicht als gevolg van de afspraak, dat vanaf ${ }^{9} 63$ Suriname's eigen bijdrage in de financiering van het Tienjarenplan gesubstitueerd zou worden door middelen, die uit het E.E.G. Ontwikkelingsfonds zouden worden ontvangen.

In I964 moest Nederland echter opnieuw overbruggingshulp verstrekken in de vorm van een lening ten bedrage van Sf. 3I,I2 miljoen,welke hulp bestemd is voor de begrotingjaren r $964 \mathrm{t} / \mathrm{m}$ I966. Suriname nam evenwel de verplichting op zich de nodige inkomstenverhogende en uitgavenverlagende maatregelen te treffen, opdat in 1967 een begrotingsevenwicht zou zijn bereikt.

Het ontstaan van de hierboven geschetste budgetaire moeilijkheden is ten dele te verklaren uit de omstandigheid dat in rg6o en volgende jaren de Tienjarenplan-investeringen veruit boven het jaargemiddelde van Sf. I2,7 miljoen stegen, waardoor er gegeven de financieringsvoorwaarden van het Tienjarenplan zware druk ontstond op de liquiditeitspositie, en de nog aanwezige financiële reserves moesten worden aangesproken. Daarbij kwam nog dat het onderhoud en de exploitatie van gereed gekomen Tienjarenplan-projecten, die ten laste van de landsbegroting kwamen, toenemende uitgaven met zich medebrachten.

De belangrijkste oorzaak van het grote uitgaven-accrès ligt evenwel in de sector van de personele uitgaven. Telde het overheidsapparaat reeds in 1959 het respectabele antal van circa I0.500 ambtenaren (inclusief losse arbeiders doch exclusief de ruim 2000 man uit de werkverschaffing), in 1964 was dit aantal toegenomen tot rond $\mathbf{5} 5.000$.

De gevoerde personeelspolitiek was grotendeels een gevolg van het feit dat de jaarlijkse toename van de beroepsbevolking, die conservatief geschat ten minste 2.500 personen telt, ver uitging boven de additionele werkgelegenheid, die in de particuliere sector kon worden gecreëerd. Anders gezegd: de Overheid stond min of meer voor de keuze van het scheppen van werkgelegenheid door middel van een sterke uitbreiding van het ambtenarencorps en dat van het instituut van de werkverschaffing òf van 
het laten ontstaan van een sterk in aantal groeiend leger van werklozen met alle daaraan verbonden repercussies. Van welke omvang het werkgelegenheidsvraagstuk in Suriname is, blijkt reeds uit het feit dat ondanks de omvangrijke kunstmatige schepping van werkgelegenheid in de overheidssector de werkloosheid onder de manlijke en vrouwelijke beroepsbevolking nog respectievelijk 7,3 en $8,2 \%$ bedraagt.

Moet derhalve zeer zeker begrip worden opgebracht voor het moeilijke dilemma, waarvoor de Regering zich geplaatst zag en voor de koers, die men meende te moeten volgen, het heeft anderzijds geen zin te verhelen, dat deze koers niet alleen geen gezonde en blijvende oplossing voor het vraagstuk bood, doch uiteindelijk ook moest leiden tot het op zich nemen van een financiële last, die ten slotte niet langer zelf gedragen kon worden en tal van moeilijkheden in een andere sector opriep. Is deze uitkomst op zichzelf reeds onbevredigend, de sterke stijging van de personele uitgaven heeft ook nog tot gevolg dat slechts geringe middelen beschikbaar komen voor de zelffinanciering van hoogst noodzakelijke ontwikkelingsactiviteiten.

Een globale analyse van de oorspronkelijke ontwerp-begroting voor het dienstjaar I964, die een tekort van Sf. I3 miljoen aangeeft, toont aan dat de personele uitgaven Sf. 45 miljoen of rond $70 \%$ van de middelen van de gewone dienst vergen. Het restant, t.w. Sf. 29 miljoen is bestemd voor materiële en andere uitgaven, terwijl voor kapitaalsuitgaven een bedrag van Sf. 24 miljoen is uitgetrokken. Hierbij zij nog opgemerkt, dat gedurende de laatste jaren ook nog ruim Sf. 4 miljoen per jaar aan personele en materiële uitgaven uit Tienjarenplan-middelen werd bekostigd. Uitgaven, die in feite ten laste van de landsbegroting zouden moeten komen, in welk geval het hierboven geschetste beeld nog ongunstiger zou uitvallen. Voorts zal in de toekomst rekening moeten worden gehouden met stijgende uitgaven ten behoeve van de aflossing en rentebetaling van opgenomen binnenlandse en buitenlandse leningen. Zo steeg het totaal van de netto-overheidsschuld van Sf. 28,8 miljoen per ultimo Ig6o tot Sf. 84,8 miljoen per 30 juni r964. Daarbij neemt de schuld uit hoofde van de lening aangegaan ten behoeve van de uitvoering van het Tienjarenplan deel voor circa $55 \%$, terwijl de overbruggingshulp en -lening tot 30 juni 1964 II \% van de netto-overheidsschuld bedroeg.

Het tot stand brengen van het noodzakelijk geachte begrotingsevenwicht impliceert evenwel dat ook in de toekomst de 
zelffinanciering door de Overheid van ontwikkelingsprojecten nog voor geruime tijd van bescheiden omvang zal zijn. Dit is begrijpelijk. Het brengt echter met zich mede dat Suriname ten behoeve van haar economische ontwikkeling naar alle waarschijnlijkheid nog voor vele jaren aangewezen is op forse buitenlandse hulp.

Het werkgelegenheidsvraagstuk kan immers alleen bevredigend worden opgelost door het scheppen van permanente werkgelegenheid in de particuliere sector. Daartoe zullen nog zeer omvangrijke accomodatie- en bedrijfsinvesteringen in de directproductieve sectoren moeten plaatsvinden en wel gedurende tal van jaren.

Over de mogelijkheid van aantrekking van het benodigde kapitaal en het bestedingstempo zal men evenwel niet al te licht mogen denken. In de eerste plaats is de kapitaalbehoefte van de gezamenlijke ontwikkelingslanden vele malen groter dan het aanbod, terwijl Suriname voorts per hoofd van de bevolking reeds groter ontwikkelingshulp ontvangt dan de meeste andere ontwikkelingslanden. Hiermede wil uiteraard niet gezegd zijn dat Suriname zich niet dient in te spannen voor het verkrijgen van meerdere ontwikkelingshulp uit diverse bronnen. Integendeel, het is een gebiedende noodzaak dat deze verkregen wordt. Doch het zal van wijs beleid getuigen rekening te houden met de werkelijkheid en het streven ook gericht te houden op een verhoging van de binnenlandse investeringen uit eigen middelen en het aantrekken van particulier kapitaal.

Indien in de nabije toekomst belangrijk grotere financiële hulp verkregen mocht worden, lijkt het wel gewenst de nodige voorzichtigheid te betrachten bij het tempo van besteding. In dit verband moge er op worden gewezen dat de ontwikkeling van de geldhoeveelheid gedurende de jaren I96I t/m I964 reeds gerede aanleiding geeft tot waakzaamheid. In 1963 en in het eerste halfjaar r964 nam de geldhoeveelheid met niet minder dan Sf. I3,7 miljoen of $26 \%$ toe en wel van Sf. 52,4 miljoen tot Sf. 66 ,I miljoen.

Indien tegenover een verdere sterke toeneming van de geldhoeveelheid een onvoldoende toeneming van de productie staat, kan dit leiden tot een nog sterkere stijging van de prijzen van binnenlands voortgebrachte goederen en van het loonpeil waardoor de toch reeds vrij kwetsbare concurrentie-positie van een aantal belangrijke Surinaamse export-producten nadelig 
wordt beïnvloed - en tot verhoogde goederen-importen met de daaraan verbonden deviezenafvloeiing.

Een gezond financieel en monetair beleid, het creëren van een zo gunstig mogelijk investeringsklimaat, een planmatige aanpak van zaken door een goed uitgerust planbureau, een opvoering van de binnenlandse besparingen en de aanwending van de te ontvangen ontwikkelingshulp voor een uitbreiding van de directproductieve sectoren vormen de pijlers, waarop ongetwijfeld een welvarend Suriname kan worden gebouwd.

Voor het verkrijgen van inzicht in de economische groei en welvaart zijn de cijfers over het nationaal inkomen van betekenis. Blijkens het U.N. Statistical Yearbook 1963 bedroeg dit inkomen (netto nationaal product tegen factorkosten) per hoofd van de bevolking van Suriname in I962 U.S. \$ 280. De cijfers voor bijvoorbeeld Nederland, Ghana, Ecuador en India bedroegen in dat jaar respectievelijk U.S. $\$ 920,170,150$, en 70.

Vanaf 1954 tot en met 1963 is in Suriname het nominaal nationale inkomen met ongeveer 6,9\% per jaar toegenomen. Aangezien het prijspeil met ongeveer $2,2 \%$ per jaar is gestegen, werd in de bewuste periode een groei van het reële nationale inkomen met ongeveer $4,7 \%$ per jaar bereikt. Daar de jaarlijkse bevolkingsaanwas gesteld kan worden op ongeveer $3,5 \%$, is het reële inkomen per hoofd per jaar met ongeveer $1,2 \%$ gestegen. Ofschoon er in de periode van I954-I963 derhalve sprake is geweest van een bescheiden economische vooruitgang, betekent zulks nog niet dat de toegenomen welvaart voor alle klassen enigszins gelijkmatig is geweest.

Voor de toekomst huldigt de Regering als doelstelling een groeipercentage van ten minste $3 \%$ per jaar voor het per capita inkomen, het cijfer dat doorgaans in de hoog-geïndustrialiseerde landen wordt bereikt. Het behoeft uiteraard geen verdere uitleg dat voor het realiseren van deze doelstelling in de eerste plaats vereist zijn aanmerkelijk hogere investeringen dan tot nu toe hebben plaats gevonden en een belangrijke opvoering van de productiviteit van het reeds bestaande productie-apparaat.

Over de beroepsbevolking en haar spreiding over de verschillende sectoren heeft de in I964 gehouden volkstelling nieuwe gegevens opgeleverd. Op een bevolkingsaantal van 328.000 bedroeg de totale beroepsbevolking - mannen en vrouwen tezamen - rond 84.00o. De verdeling over de verschillende sectoren in 
percenten is als volgt:

$\begin{array}{lrlr}\text { landbouw en visserij } & 33,3 & \text { mijnbouw } & 4,4 \\ \text { overheid } & \text { I9,0 } & \text { constructie } & 4,3 \\ \text { handel en transport } & \text { I2,3 } & \text { bosbouw } & \text { I,8 } \\ \text { nijverheid } & \text { Io,8 } & & \\ \text { diensten } & 6,6 & \text { werkloos } & 7,5\end{array}$

Uit deze cijfers blijkt vooreerst dat het aantal personen dat werkzaam is in de direct productieve sectoren slechts $54,6 \%$ bedraagt. In het oog springend is voorts het hoge percentage van bij de overheid werkzame personen, waarvoor hierboven reeds een verklaring is gegeven.

Het aantal agrarische beroepsbeoefenaars is in vergelijking tot vroegere cijfers vrij sterk verminderd. De belangrijkste oorzaken daarvan zullen wel zijn de toenemende trek van plattelandsbewoners naar de stad en het verschijnsel dat zonen van landbouwers in toenemende mate een beroep buiten de agrarische sector verkiezen. Een tendens, die zich overal elders ter wereld ook voordoet.

Ofschoon de landbouw toch nog steeds het grootste deel van de beroepsbevolking omvat, draagt deze bedrijfstak relatief weinig bij in het nationaal product (werkgelegenheid 33,3\%, nationaal inkomen 10\%). In deze situatie kan verbetering worden gebracht door een opvoering van de productiviteit en de verbouw van hoogwaardiger gewassen, waarmede reeds een aanvang is gemaakt.

De mijnbouw daarentegen, waarin slechts $4,4 \%$ van de beroepsbevolking werkzaam is, levert het belangrijkste aandeel in het nationale inkomen nl. $28,5 \%$

Ten aanzien van de ontwikkeling van het prijs- en loonniveau kan in het kort het volgende worden opgemerkt.

Reeds werd terloops aangestipt dat het prijspeil in de periode I $954 \mathrm{t} / \mathrm{m}$ I 963 met ongeveer $2,2 \%$ per jaar is gestegen. In vergelijking tot andere landen is deze stijging zeker niet bijzonder verontrustend, zij het dat er aspecten aan verbonden zijn, die tot nadenken en waakzaamheid nopen.

In de eerste plaats dient er op te worden gewezen dat de prijsstijging bij de groep goederen van buitenlandse oorsprong betrekkelijk gering was. Ten dele werd zij veroorzaakt door prijsstijgingen in het buitenland, voor het overige door verhogingen van het invoerrecht op bepaalde artikelen, die uit hoofde van 
protectionistische of budgetaire redenen werden afgekondigd.

De grootste stijging vond evenwel plaats bij de producten van Surinaamse oorsprong en wel bij de voedingsmiddelen in het bijzonder. Ook na uitschakeling van de seizoensinvloeden, die een sterk fluctuerend prijspeil gedurende de loop van het jaar veroorzaken, blijkt dat het indexcijfer voor in Suriname geteelde voedingsgewassen en fruit gedurende de laatste jaren een sterke tendens tot stijgen vertoont. De oorzaken van deze ontwikkeling zijn het achterblijven van de productie bij een toenemende vraag en het gebrekkige distributieapparaat, waarbij de dominerende rol van opkopers en detailhandelaren kostenverhogend werkt. Daar het hier in het algemeen primaire levensbehoeften betreft, lijkt het alleszins gewenst dat krachtig gestreefd wordt naar een eliminatie van de prijsverhogende factoren.

Over de ontwikkeling van het loonpeil zijn geen exacte cijfers beschikbaar, althans niet in die zin dat zij min of meer als maatgevend voor het gehele bedrijfsleven kunnen worden beschouwd. Karakteristiek voor Suriname is nl. de grote differentiatie die, zelfs binnen dezelfde bedrijfstak, op het terrein van de lonen bestaat. Dit is één van de hoofdoorzaken dat het systeem van collectieve arbeidsovereenkomsten, geldend voor een gehele bedrijfstak, nog geen ingang heeft kunnen vinden in Suriname. De grote verscheidenheid in lonen is echter veelal het behoud geweest voor de vele kleine marginale bedrijven, die zich niet de door grote, buitenlandse ondernemingen betaalde hogere lonen kunnen veroorloven.

Aangenomen mag worden dat het loonniveau, geldend bij laatstgenoemde groep van ondernemingen, in de afgelopen jaren niet onbelangrijk is gestegen, zeker wat betreft de honorering van geoefende en geschoolde arbeidskrachten. Naar alle waarschijnlijkheid zal deze verhoging de stijging van het indexcijfer van de prijzen van levensonderhoud hebben overtroffen.

Ofschoon het Surinaamse loonpeil in vergelijking tot de WestEuropese loonstandaard nog laag genoemd kan worden, dient volledigheidshalve te worden vermeld dat de naar Nederlands patroon, doch in beperkter omvang, tot stand gekomen sociale wetgeving kortgeleden werd uitgebreid, hetgeen uiteraard een kostenverhoging voor het bedrijfsleven met zich medebracht.

Ten behoeve van de noodzakelijke vergroting van de export zal er voor gewaakt moeten worden dat het loonpeil en de secundaire arbeidsvoorwaarden niet zodanig worden opgevoerd, 
dat de concurrentiepositie van de meeste Surinaamse exportproducten, die reeds door andere oorzaken minder gunstig is, verder wordt aangetast.

De weinige stakingen daargelaten, stonden de afgelopen tien jaren in het teken van een grote arbeidsrust. De samenwerking tussen de Overheid, het georganiseerde bedrijfsleven en de vakbeweging was uitstekend.

De ontwikkeling van de in- en uitvoer valt af te lezen uit onderstaande cijfers. (Algemeen Bureau voor de Statistiek. - Invoer en uitvoer inclusief wederinvoer en wederuitvoer.)

\begin{tabular}{|c|c|c|c|c|}
\hline Jaar & $\begin{array}{l}\text { Invoer } \\
\text { in } \mathrm{mi}\end{array}$ & $\begin{array}{l}\text { Uitvoe } \\
\text { joener }\end{array}$ & $\begin{array}{l}\text { Invoer- } \\
\text { verschot } \\
\text { ldens }\end{array}$ & $\begin{array}{l}\text { Dekkings- } \\
\text { percentage }\end{array}$ \\
\hline I955 & $5^{\mathrm{I}, 7}$ & 50,4 & $\mathrm{I}, 3$ & 98 \\
\hline I958 & $7 \mathrm{I}, 4$ & 62,3 & $9, \mathrm{I}$ & 87 \\
\hline I960 & I02,0 & 82,5 & I 9,5 & $8 \mathrm{I}$ \\
\hline 1962 & I03,0 & 80,0 & 23,0 & 78 \\
\hline I963 & III,, & 87,5 & 22,7 & 79 \\
\hline
\end{tabular}

Het verloop van de totale in- en uitvoer vertoont tot op zekere hoogte enige gelijkenis met dat van de landsbegroting. Was daar sprake van een snelle, sprongsgewijze stijging van de uitgaven, waartegenover geen evenredige stijging van de inkomsten stond, hier zien wij een vrijwel even snelle en forse stijging van het invoervolume en een achterblijven van de groei van de export, resulterend in een duidelijke verslechtering van het dekkingspercentage van de invoer door de uitvoer.

In de sterke groei van het invoervolume weerspiegelen zich de toegenomen investeringsactiviteiten in het kader van het Tienjarenplan en het Brokopondoproject, het hoge bestedingspeil van de Overheid, het sterk in omvang toenemende afbetalingscrediet, dat overheidsingrijpen wenselijk maakt, en de uitzetting van het bankcrediet.

Nadat ter voorkoming van een te sterke verdere afvloeiing van deviezen in 1962 een aantal restrictieve monetaire maatregelen getroffen moest worden, kon een verdere uitzetting van het invoervolume belangrijk worden ingeperkt. $\mathrm{Na}$ afschaffing van deze maatregelen zette de groei zich echter weder voort.

Een sterke toename van het invoervolume is een veel voorkomend en in feite normaal verschijnsel bij landen, die zich in 
een opgaande ontwikkeling bevinden en dringend behoefte hebben aan investeringsgoederen en grondstoffen. Of evenwel sprake is van een onder de gegeven omstandigheden gezonde ontwikkeling, die gecontinueerd kan worden, hangt onder meer af van de vraag of eveneens een bevredigende stijging van de export plaatsvindt en of de deviezenaanwas in het algemeen evenredig is aan deviezenafvloeiing ten gevolge van hogere bestedingen in het buitenland. Tenslotte is de richting van de buitenlandse bestedingen van belang.

Uit de genoemde cijfers blijkt vooreerst dat de stijging van het exportvolume in een te traag tempo verloopt. Afgewacht dient te worden of de in 1963 plaatsgehad hebbende vooruitgang blijvend is, aangezien factoren van vermoedelijk slechts incidentele aard de export in dat jaar hebben gestimuleerd.

De wijze van besteding bij de invoer gedurende de laatste jaren kan worden afgelezen uit onderstaande tabel. (Ontleend aan het Algemeen Bureau voor de Statistiek.)

$\begin{array}{lllll}1959 & I 960 & 1961 & 1962 & 1963\end{array}$ in procenten

\begin{tabular}{|c|c|c|c|c|}
\hline Brandstoffen, smeermidd. e.d. & 8,0 & 7,6 & 7 , & 9,I \\
\hline $\begin{array}{l}\text { Grondstoffen en hulpstoffen } \\
\text { e.d., garens en weefsels } \\
\text { Consumptiegoederen. perso- }\end{array}$ & 33,6 & 34,9 & 36, & 40,8 \\
\hline $\begin{array}{l}\text { Consumptiegoederen, perso- } \\
\text { nenauto's en motorrijwielen }\end{array}$ & 34,0 & 33,7 & 34, & 32,8 \\
\hline Investeringsgoederen & 24,4 & 23,8 & $2 \mathrm{I}$, & 17,3 \\
\hline
\end{tabular}

Verheugend is het stijgend aandeel in de invoer van de categorie: grond- en hulpstoffen, hetgeen een indicatie oplevert voor een verhoogde bedrijvigheid in de industriële bouwsector. Daartegenover staat echter een vrijwel continue relatieve vermindering van de invoer van kapitaalgoederen. Het aandeel van de consumptiegoederen in de totale invoer, gemiddeld circa $32 \%$ bedragend, lijkt te groot voor een land in opbouw dat bovendien nog te kampen heeft met een acuut werkgelegenheidsvraagstuk.

Een analyse van de betalingsbalans toont aan dat de positie van de lopende rekening de laatste tijd van jaar tot jaar verslechterd is. Hieraan hebben alle drie onderdelen van deze rekening t.w. de handelsbalans, de dienstenbalans en de kapitaal- 
opbrengstenbalans, bijgedragen. Een en ander wijst op een minder bevredigende economische en monetaire ontwikkeling.

Ten aanzien van het verloop van de uitvoer werd er reeds op gewezen dat het groeipercentage minder groot was dan wel wenselijk zou zijn geweest. Doch ook een tweetal andere aspecten, die in zeker verband tot elkaar staan, stemmen tot nadenken. In de eerste plaats bleef de overheersende positie van slechts één product, de bauxiet, in het exportpakket gedurende de gehele tienjarige periode vrijwel ongewijzigd voortbestaan. Ook de samenstelling van het exportpakket bleef vrij constant, zij het dat in dit opzicht een vooralsnog bescheiden verbreding van de basis tot uitdrukking kwam.

De traditionele Surinaamse exportartikelen uit de laatste decennia zijn bauxiet, een aantal agrarische producten (rijst, citrusfruit, koffie, cacao en suiker), enkele bosproducten en half-fabrikaten daarvan (vierkant bekapt hout, rondhout, dwarsliggers, triplex, gezaagd hout en balata) en ten slotte enkele andere artikelen (vnl. confectiekleding). In de loop van I954-I964 zijn als nieuwe bestanddelen van het exportpakket naar voren gekomen: alcohol (rum en spiritus), garnalen, bacoven, sinaasappelconcentraat en spaanplaten. Producten, die met uitzondering van het laatste artikel, van agrarische oorsprong zijn.

Wat volume betreft bleef de bauxiet-uitvoer op een vrij constant niveau, variërend tussen 3 en 3,5 miljoen metrieke tonnen. $\mathrm{Na}$ de totstandkoming van de Brokopondo-overeenkomst nam ten gevolge van de in deze overeenkomst opgenomen verrekenprijzen voor bauxiet de waarde van Suralco's aandeel in de uitvoer sedert I96I toe.

In de jaren I954-I956 bedroeg de uitvoerwaarde van bauxiet ongeveer $80 \%$ van de totale uitvoerwaarde (exclusief wederuitvoer), terwijl dit percentage voor de jaren I96r, I962 en I963 respectievelijk 83, 79 en 77 bedroeg (waardecijfers resp. Sf. 64,3, Sf. 62,5 en Sf. 66,I miljoen). Wijst het dalend aandeel van de bauxiet in de totale uitvoer derhalve op een gunstige ontwikkeling van de uitvoer van andere export-goederen - in casu van agrarische producten -, het betekent nog niet dat de afhankelijkheid van Suriname 's economie van één enkele grondstof spoedig tot het verleden zal behoren. Eerder zal deze afhankelijkheid in de toekomst vergroot worden. Immers na gereedkoming van de aluinaarde fabriek en aluminiumsmelter in I965 en na het in 
exploitatie komen - zulks in een later stadium - van de nieuwe bauxietvoorkomens in West-Suriname, zal de totale uitvoerwaarde van bauxiet, aluinaarde en aluminium tezamen zeer aanzienlijk toenemen en daarmede ook de afhankelijkheid van het conjunctuurverloop bij de aluminiumindustrie.

De omvang van de agrarische export en haar aandeel in de totale uitvoerwaarde vertoonde in de loop der jaren een enigszins wisselend beeld als gevolg van goede of slechte weersomstandigheden, het prijsverloop bij bepaalde producten e.d. Niettemin is er sprake van een geleidelijke stijging van de waarde van de agrarische uitvoer, die in het bijzonder sedert I96I tot uitdrukking kwam. De uitvoerwaarde en het aandeel in de totale uitvoer gedurende de laatste drie jaren was namelijk als volgt:

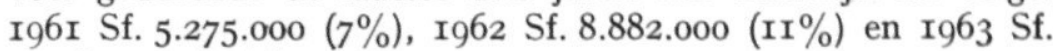
II.I80.000 (13\%).

Tot het gunstige resultaat in 1963 hebben vooral bijgedragen een stijging ter waarde van Sf. 500.000 bij de garnalenuitvoer, de export van het nieuwe product sinaasappelconcentraat voor een bedrag van Sf. 700.000 , en een sterke stijging van de suikeruitvoer, die begunstigd werd door een hoge wereldmarktprijs en in totaal Sf. I,7 miljoen bedroeg (de uitgevoerde hoeveelheid was ruim $300 \%$ meer dan de gemiddelde uitvoer over de jaren 1959I962). Nu kort geleden de sappenfabriek tijdelijk buiten bedrijf moest worden gesteld en de wereldmarktprijs voor suiker weer enigszins dalende is, zal moeten worden afgewacht of de uitvoerstijging, behaald met de producten suiker en sinaasappelconcentraat kan worden gecontinueerd c.q. bij daling gecompenseerd kan worden door een vermeerderde uitvoer van andere agrarische producten.

In het agrarisch exportpakket bleef rijst de belangrijkste plaats innemen.De uitvoer van dit product gedurende de jaren I96I t/m I963 had een waarde van achtereenvolgens rond Sf. 4,3 mln, Sf. 4,9 mln en Sf. 5,I mln. Verreweg het grootste deel van de voor export bestemde rijst was afkomstig van het door Nederland gefinancierde Wageningenproject.

De uitvoercijfers van koffie en cacao vertoonden de laatste jaren een dalende tendens, die veroorzaakt werd door prijsdaling (koffie) en periodieke droogte-schade (cacao). Daartegenover staat een bevredigende continue stijging van de uitvoer van garnalen en van het eveneens nieuwe exportproduct bacoven $=$ bananen (I96I Sf.86.000, I963 Sf. 218.000). Na voltooiing van 
het uit Tienjarenplan-middelen gefinancierde 'bacovenproject' zal de uitvoer van dit product nog belangrijk toenemen.

Samengevat kan worden gesteld dat de agrarische uitvoer, zowel wat volume, waarde, als samenstelling betreft, in het bijzonder gedurende de laatste jaren zich bevredigend heeft ontwikkeld en betere perspectieven biedt dan voorheen. Dit is bijzonder verheugend, indien in aanmerking wordt genomen dat wisselende weersomstandigheden en de prijsgevoeligheid van de meeste agrarische producten remmend werken bij het tot ontwikkeling brengen van de landbouwkundige sector.

De derde plaats in het exportpakket - in I96r was dit nog de tweede - wordt ingenomen door de bosproducten en halffabrikaten daarvan. Ook in deze sector vond een bevredigende ontwikkeling plaats en een stijging van het uitvoervolume en van de waarde, die in de jaren 1961, 1962 en 1963 was toegenomen tot achtereenvolgens rond Sf. 6,94 mln, Sf. 6,97 mln en Sf. 8,I7 mln.

Ruim $80 \%$ van deze uitvoer bestaat uit triplex, spaanplaten en gezaagd en geschaafd hout, producten die vervaardigd worden door de Bruynzeel Suriname Hout Mij. Het stemt tot grote tevredenheid dat de export van deze artikelen zich niet alleen heeft weten te handhaven, doch ook nog een geleidelijke toeneming vertoont. Juist in deze sector doen zich bij herhaling grote afzetmoeilijkheden voor, welke veroorzaakt worden door scherpe concurrentie van de zijde van andere goedkope productielanden en door protectionistische maatregelen in nabuurlanden en in de Verenigde Staten van Amerika. Van de overige producten uit de bosbouwkundige sector kunnen nog worden genoemd vierkant bekapt hout en balata, die eveneens scherpe concurrentie ondervinden uit andere productielanden.

$\mathrm{Na}$ de voorgaande beschouwing over Suriname's in- en uitvoer kunnen, naar het voorkomt, de volgende conclusies worden getrokken. In de eerste plaats lijkt het alleszins gewenst op korte termijn te streven naar een gunstiger dekkingspercentage van de invoer door de uitvoer, hetgeen bereikt kan worden enerzijds door importvervangende en -beperkende maatregelen, in het bijzonder op het terrein van de invoer van consumptie- en luxe goederen en anderzijds door een opvoering van de export.

Ten aanzien van laatstgenoemde mogelijkheid zijn de vooruitzichten niet ongunstig. Na gereedkoming van Suralco's aluinaardefabriek en aluminiumsmelter in 1965 zullen nieuwe producten worden toegevoegd aan het exportpakket die een 
hogere waarde vertegenwoordigen dan onverwerkte bauxiet. Aangezien voorlopig slechts $10 \%$ van de huidige jaarlijkse bauxietproductie verwerkt zal worden, zal de hieruit resulterende hogere uitvoerwaarde voorshands van beperkte omvang zijn. Na de uitgifte van exploratie- en exploitatievergunningen voor de in West-Suriname ontdekte nieuwe bauxietvoorkomens zal echter na verloop van tijd de totaalwaarde van uitgevoerde bauxiet, aluinaarde en aluminium nogmaals - en ditmaal - een forse stijging vertonen.

Zoals reeds betoogd zal de afhankelijkheid van Suriname's economie van het conjunctuurverloop bij de aluminium-industrie daardoor nog meer worden vergroot, zodat het, meer nog dan voorheen, wenselijk is te komen tot een grotere diversificatie van het exportpakket. Daarbij dient evenwel te worden bedacht dat een aantal factoren remmend werkt bij het streven naar een vergroting van de export. Als zodanig kunnen worden genoemd: geringe afzetmogelijkheden van producten in nabuurlanden ten gevolge van protectionistische maatregelen en andere factoren, de hoge koerswaarde van de Surinaamse gulden, die belemmerend kan werken bij de uitvoer naar West-Europa, hoge vrachtkosten,en dergelijke. Mede in dit licht bezien zal de nodige aandacht besteed dienen te worden aan de handhaving van een zo laag mogelijk productie-kostenpeil en aan het voeren van een politiek van actieve exportbevordering, die mede gericht is op het elimineren van exportbelemmerende factoren voor zover zulks mogelijk is. Voorts zou kunnen worden nagegaan of van Nederlandse zijde steun c.q. faciliteiten kunnen worden verleend bij de afzet van Surinaamse producten in Nederland.

Ten aanzien van de richting van het handelsverkeer kan worden medegedeeld dat gedurende de laatste drie jaren de belangrijkste leveranciers-landen waren de Verenigde Staten van Amerika, op de voet gevolgd door Nederland, die tezamen ruim $60 \%$ van Suriname's invoer verzorgen. Van de uitvoer ging $70-75 \%$ naar de Verenigde Staten (bauxiet, garnalen, sinaasappelconcentraat, houtproducten). De belangrijkste overige afnemers van Surinaamse producten zijn in vogorde: Nederland (vnl. agrarische en houtproducten), Canada (bauxiet), Caraibisch gebied (houtproducten en rijst) en de West-Duitse Bondsrepubliek (vnl. rijst).

Nadat in de voorgaande pagina's een aantal aspecten van meer algemene aard zijn belicht, volgt thans een korte beschrijving van 
de ontwikkeling in de belangrijkste productiesectoren en van de perspectieven, die zij bieden.

Mijnbouwkundige sector

De in deze sector gewonnen producten omvatten momenteel slechts goud, steenslag en bauxiet, dat verreweg het belangrijkste voortbrengsel van Suriname is. De producenten hiervan zijn Suralco, een dochteronderneming van de Aluminum Company of America en sedert I939 ook de Billiton Mij Suriname. Gedurende de laatste jaren is Suralco's aandeel in de totale bauxietproductie geleidelijk aan verminderd en dat van de Billiton Mij Suriname toegenomen. Ten behoeve van de mechanisatie van het ontginningsproces en tot verbetering van de verschepingsfaciliteiten hebben beide bedrijven regelmatig grote investeringen gepleegd. Begunstigd door het stagneren van de bauxietproductie in Brits Guyana, waardoor de vaste afnemers van deze productie hun behoeften voor een gedeelte elders moesten dekken, wist de Billiton Mij in I963 een recorduitvoer van 1,2 miljoen metrieke tonnen (totale uitvoer $3,48 \mathrm{mln}$ ton) te bereiken, nadat reeds in I960 en I96I een export van meer dan I miljoen ton was behaald.

Van welk een grote betekenis de bauxietproductie voor Suriname's economie is, blijkt duidelijk uit de volgende percentages. Het Land verkrijgt circa $26 \%$ van zijn lopende inkomsten uit de activiteiten van de beide bauxietmaatschappijen, terwijl zoals reeds eerder vermeld de uitvoerwaarde van bauxiet ongeveer $80 \%$ van de totale uitvoerwaarde bedraagt. Aan het nationaal inkomen tegen factorkosten draagt de mijnbouw voor circa $28,5 \%$ bij.

Na gereedkoming van het Brokopondo-project, zal de betekenis van de bauxietwinning voor de Surinaamse economie nog meer toenemen. Na grondige voorbereiding en langdurige onderhandelingen met de Surinaamse regering werd in 1958 een aanvang gemaakt met de uitvoering van dit project, dat een geesteskind is van Prof. Dr. Ir. W. van Blommestein. Het plan omvat de bouw van een stuwdam en waterkrachtwerk (opgewekt vermogen I50.000 kW.) in de Surinamerivier bij Afobaka, de aanleg van een weg en hoogspanningsleiding van Paramaribo naar Afobaka, de bouw van een aluminiumsmelter bij Paranam en uiterlijk I2 jaar later van een aluinaardefabriek. De bouw van dam, waterkrachtwerk, hoogspanningsleiding, smelter en aluinaardefabriek worden gefinancierd door Suralco. 
Op I februari 1964 kon de dam worden gesloten en werd een begin gemaakt met de constructie van de aluminiumsmelter en aluinaardefabriek, die beide omstreeks medio I965, op het tijdstip dat de waterkrachtcentrale in werking zal komen, gereed zullen zijn. Tot de vervroegde bouw van de aluinaardefabriek heeft vooral bijgedragen een tussen Suralco en Billiton gesloten overeenkomst, waarbij Suralco een deel van de capaciteit van de aluinaardefabriek ter beschikking zal stellen van de Billiton voor de verwerking van bauxiet tot aluinaarde. Door deze overeenkomst komt de aluinaardefabriek niet alleen eerder in productie, doch zij wordt ook groter dan oorspronkelijk de opzet was.

Ten aanzien van de toekomstige ontwikkeling van de bauxietwinning dient nog gewezen te worden op de betrekkelijk recente ontdekking van grote bauxietvoorkomens, geraamd op 270-400 miljoen ton, in het Adampada-Kabalebogebied bij det Bakhuysgebergte in West Suriname. Voor het verkrijgen van concessierechten voor de exploratie en exploitatie van deze voorkomens hebben verscheidene grote maatschappijen, waaronder Suralco en de Billiton, belangstelling aan de dag gelegd. Medio 1963 diende de huidige Regering een Ontwerp-Landsverordening bij de Staten in, tot het verlenen van machtiging aan de Regering om een overeenkomst aan te gaan met de Suriname Mineral Corporation - een dochteronderneming van de Amerikaanse aluminiumproducent Ormet - waarbij aan deze maatschappij concessierechten zouden worden verleend voor de exploitatie van eerdergenoemde bauxietvoorkomens. Tegen dit ontwerp rees in de Staten veel verzet, onder andere omdat in de ontwerp-overeenkomst de verplichting tot verdere verwerking van de bauxiet, zelfs tot aluinaarde, niet voldoende en bevredigend tot uitdrukking was gebracht. Het bewuste ontwerp werd enkele maanden geleden ingetrokken en de Regering heeft thans kenbaar gemaakt dat een zo groot mogelijke verwerking tot aluinaarde en aluminium dient plaats te vinden om voor een concessie in aanmerking te kunnen komen. Door Prof. Van Blommestein, die momenteel de Surinaamse Regering adviseert over aangelegenheden op het terrein van waterkrachtwerken en irrigatie, is gewezen op de mogelijkheid van de bouw van een stuwdam in de Kabaleborivier met afleiding van water uit enkele zijrivieren van de Corantijn, waardoor een vermogen van 1500 Megawatt zou kunnen worden opgewekt (een vermogen tien maal zo groot als dat van het Brokopondo waterkrachtwerk). Door middel van de aanleg van additionele kunstwerken zou dit project tevens benut 
kunnen worden voor het creëren van een waterweg ten behoeve van de afvoer van de verwerkingsproducten en voor een verbetering van de irrigatiemogelijkheden in West Suriname. Ofschoon nimmer exacte cijfers zijn bekendgemaakt over de totale investeringskosten, welke met de uitvoering van dit Kabalebo project zijn gemoeid, ligt het in de lijn der verwachting, dat deze het veelvoud van de Brokopondo-investeringen zullen bedragen. Het maken van een voorstudie van dit project is kortgeleden opgedragen aan het Duitse Salzgitter-concern (Salzgitter Industriebau Gesellschaft).

Of het Kabalebo-project in de vorm zoals door Prof. Van Blommestein ontwikkeld, gerealiseerd zal worden, hangt af van de vragen of het plan technisch en economisch bezien uitvoerbaar is, of de vereiste financieringsmiddelen kunnen worden verkregen en of er aluminiummaatschappijen zijn, die bereid zijn een vergaande verwerkingsplicht te aanvaarden. Het antwoord op deze laatste vraag zal grotendeels afhangen van de omvang van de smeltercapaciteit, waarover de grotere aluminiumproducenten reeds beschikken en van reeds bestaande plannen tot uitbreiding van deze capaciteit elders ter wereld.

De goudproductie, die in de jaren I905-I9Io jaarlijks circa Iooo $\mathrm{kg}$ bedroeg, is sedertdien gestadig in omvang afgenomen. Werd in $1955 \mathrm{nog}$ slechts $225 \mathrm{~kg}$ geproduceerd, in de daarop volgende jaren zette de productiedaling zich verder voort tot in 1962 een dieptepunt werd bereikt met een productie van rond $8 \mathrm{I} \mathrm{kg}$.

Reeds enkele jaren geleden werd door de grootste producent, de Sarakreek Goudvelden N.V., een belangengemeenschap aangegaan met een Canadese onderneming. In het kader van deze samenwerking werd besloten tot oprichting van een nieuwe maatschappij, de Lawa Goudvelden Mij en tot een kostbare mechanisatie van het goudwinningsprocess. Door het in gebruik nemen van een baggermolen kon vorig jaar de productie weer worden opgevoerd, zodat de totale binnenlandse productie steeg tot IIo $\mathrm{kg}$. Een verdere stijging ligt in de lijn der verwachting.

In $195^{8}$ werden aan de Colmar Surinam Oil $\mathrm{Cy}$, een dochteronderneming van de Amerikaanse Gulf States Land and Industries Inc., concessierechten voor de exploratie naar olie verleend in een zee- en landgebied ter grootte van $56.000 \mathrm{~km}^{2}$. Sedertdien is ruim US $\$$ I mln. besteed aan geologisch en geofysisch onderzoek. Nadat indicaties voor de aanwezigheid van olie waren ver- 
kregen, werd in de laatste maanden van 1963 begonnen met boringen in zee op ongeveer $80 \mathrm{~km}$ van de kust. Deze boringen welke na enkele maanden werden afgebroken, werden door de Gulf States Land and Industries Inc. verricht in samenwerking met een groep Franse oliemaatschappijen, die onder leiding staat van het Franse Staatsbedrijf Bureau de Recherches de Pétroles. Bedoelde groep had een belang verworven in de Surinaamse concessie.

Naar aanleiding van een voorgenomen wijziging van de Landsverordening, waarbij aan de Colmar Surinam Oil Cy concessierechten zijn verleend, worden thans onderhandelingen gevoerd tussen de Regering en de Amerikaans-Franse groep over de capaciteit van een in Suriname te bouwen raffinaderij, indien olie in exploiteerbare hoeveelheden wordt aangeboord. Volgens de huidige plannen zullen de zeeboringen in 1965 worden voortgezet.

Ter verkrijging van een zo betrouwbaar mogelijk inzicht in het voorkomen van delfstoffen werd in $195^{8}$ een aanvang gemaakt met een grootscheepse geologische mijnbouwkundige exploratie van het gehele Surinaamse grondgebied, de zg. 'Operatie Sprinkhaan'. Begonnen werd met een luchtgeofysisch onderzoek. De hierbij verkregen indicaties van het voorkomen van mineralen worden nader onderzocht door grondploegen van de Geologisch Mijnbouwkundige Dienst, teneinde vast te stellen welke mineralen, en in welke hoeveelheden, aanwezig zijn. Het moeilijk toegankelijke binnenland werd hiertoe ontsloten door middel van een zevental basis-vliegvelden. Het terrestrische exploratieprogramma zal zeven jaren in beslag nemen, waarvan reeds drie jaren achter de rug zijn.

Tot en met I963 werd aan dit project Sf. 5.6 miljoen ten laste van het Tienjarenplan besteed. In dit bedrag zijn de onderhoudskosten van de vliegvelden niet begrepen. Het totale bedrag dat in de periode $1954-1963$ uit het Tienjarenplan ten behoeve van de Mijnbouwkundige sector werd uitgegeven, bedroeg ruim Sf. II miljoen.

Ten aanzien van het voorkomen van andere mineralen dan bauxiet en goud kan het volgende worden medegedeeld. Reeds bekend door vroegere geologische exploraties of aangetoond in het kader van de Operatie Sprinkhaan zijn de aanwezigheid van zeer grote afzettingen van lateritisch ijzererts zowel in West- 
Suriname als rond het Brokopondostuwmeer, van hoogwaardig chroomerts, en van indicaties van nikkel en mangaan. Of laatstgenoemde ertsen in economisch exploiteerbare hoeveelheden voorkomen, zal moeten worden afgewacht. Het onderzoek hiernaar wordt voortgezet.

Blijkens een in 195I verschenen publicatie van het Nederlands Economisch Instituut te Rotterdam werden de vestigingsvoorwaarden voor een hoogovenbedrijf met het aanwezige lateritisch ijzererts te Donderbari toentertijd ongunstig beoordeeld. Het erts was laagwaardig (ca $35 \% \mathrm{~F} 2$ ), de benodigde cokes moest worden ingevoerd (smelting in kleine houtskool- of electrische ovens was onrendabel), de afstand van de vindplaats Donderbari tot de kust was vrij groot en moeilijk, terwijl de afzet van het erts naar de staalproducerende landen van Midden- en Zuid-Amerika en de U.S.A. economisch ondoenlijk was. De meeste hunner beschikten over eigen reserves van veel hoogwaardiger ijzererts of konden dat voordeliger uit meer nabij gelegen landen betrekken.

Door de ontdekking van de lateritische ijzerertsafzettingen in West-Suriname en de mogelijkheid van oprichting van een waterkrachtwerk aldaar, is opnieuw aandacht aan deze ertsvoorkomens geschonken. Nadat omstreeks medio I964 een deskundige van de Verenigde Naties een onderzoek naar eventuele verwerkingsmogelijkheden van dit ijzererts heeft ingesteld, werd daarna aan het Salzgitter-concern opdracht verleend eveneens een voorstudie hierover op te stellen.

Agrarische sector

Tijdens de opstelling van het Tienjarenplan werd gemeend dat bij het streven naar een uitbreiding en uitbouw van de landbouw het accent op de kleinlandbouw gelegd diende te worden en niet op de ondernemingslandbouw. De redenen hiervoor leken voor de hand liggend. In de eerste plaats kwam in 1950 circa $90 \%$ van de totale waarde van de landbouwproductie voor rekening van de kleinlandbouw, waarin ook het grootste deel van de beroepsbevolking werkzaam was en waarvan het inkomen per hoofd verhoogd diende te worden. Voorts werden de vooruitzichten van de plantagelandbouw weinig rooskleurig geacht in verband met het beperkte landarbeidersreservoir, de geringe mechanisatiemogelijkheden op de met kanalen en sloten doorsneden oude plantagegronden, het relatief hoge loonpeil en de onvoldoende kapitaalvoorziening, waardoor de productie-eenheden veelal te 
klein blijven, doch niettemin hoge 'overhead'-kosten hebben, waardoor de kostprijs nadelig wordt beïnvloed.

Indien in aanmerking wordt genomen, dat na de verkeerssector aan de agrarische sector het grootste percentage van Tienjarenplanmiddelen is besteed, dan ontkomt men niet aan de indruk, dat de tot nu toe behaalde resultaten in bepaalde opzichten teleurstellend zijn geweest. De volgende cijfers, ontleend aan het Ministerie van Landbouw, geven aanleiding tot deze veronderstelling.

Het totale beplante areaal (kleinlandbouw + grootlandbouw) steeg in afgeronde cijfers van circa 38.000 ha in 1957 tot 40.400 in 1959 en bedroeg 39.400 ha in de jaren I 962 en I 963 . Bij een beoordeling van deze cijfers dient rekening te worden gehouden met het feit dat de weersomstandigheden gedurende de laatste jaren over het algemeen zeer wisselvallig en ongunstig zijn geweest, terwijl tevens het areaal beplant door grote landbouwbedrijven in de periode $1959 \mathrm{t} / \mathrm{m}$ I 962 vrij grote fluctuaties vertoonde (laagste cijfer I2.700 ha en hoogste cijfer I4.700 ha). Anderzijds kan niet worden ontkend dat omvangrijke bedragen zijn geïnvesteerd in de sanering van bestaande doch niet volledig in cultuur genomen arealen en de aanleg van nieuwe polders, zodat een forsere uitbreiding van het landbouwareaal verwacht had mogen worden.

De cijfers over het verloop van de totale waarde van de productie van landbouw en veeteelt (herleid tegen prijzen van I954) geven een gunstiger beeld, zoals uit onderstaande cijfers blijkt.

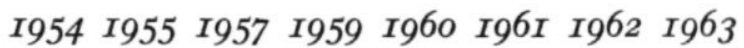

waarde in miljoenen

$\begin{array}{lllllllll}\text { Sur. guldens } \quad I 6, I & \text { I6,2 } & \text { I5,8 } & 20,0 & 20,9 & \text { I9, I } & 22,0 & 22,5\end{array}$

In deze cijfers zijn echter begrepen de producties van de plantages, die de gehele suiker- en cacaoteelt en het grootste deel van de citrus- en koffieproductie voor hun rekening nemen. Voorts de rijstopbrengst van het Wageningenproject ter waarde van circa Sf. 2,6 mln gemiddeld per jaar in de periode $1957 \mathrm{t} / \mathrm{m}$ I96o en van Sf. 4,I mln in de jaren I96r t/m I963. In dit verband kan nog worden opgemerkt dat het aandeel van de ondernemingslandbouw in de agrarische export (exclusief visserijproducten) 
naar schatting $80-85 \%$ heeft bedragen. In de jaren I962 en I963 zal dit percentage vermoedelijk nog hoger zijn geweest. Immers de verheugende stijging van de agrarische uitvoer in die jaren komt voor het grootste deel voor rekening van de grootlandbouw (de exporttoename van vers citrusfruit, concentraat, suiker en Wageningen-rijst).

In deze samenhang bezien lijkt de conclusie gerechtvaardigd dat de groei van de kleinlandbouw, zowel wat beplant areaal als volume en productiewaarde betreft, zeker niet aan de gestelde verwachtingen heeft voldaan.

Is deze conclusie op zichzelf teleurstellend, zij mag er zeker niet toe leiden dat een verdere sterke bevordering van de landbouw voortaan achterwege blijft. De oorzaken van de hierboven geschetste minder bevredigende ontwikkeling zijn namelijk begrijpelijk en in het algemeen niet van dien aard, dat geen verbetering mogelijk is.

In de eerste plaats werd men gehandicapt door het gemis aan een doelbewust en gericht landbouwbeleid, hetgeen mede het gevolg was van het ontbreken van tal van essentiële statistische gegevens en het gemis aan ervaring op het terrein van een planmatige aanpak der kernproblemen. Voorts werd de aandacht te veel geconcentreerd op een eenzijdige bevordering van de rijstcultuur, welke mede geïnspireerd werd door de gedachte dat de hoge na-oorlogse rijstprijzen gehandhaafd zouden blijven. Er zijn landsanerings- en landaanwinningsprojecten uitgevoerd, zonder dat voldoende zekerheid bestond dat in tijden van scherpe droogte een redelijke bevloeiing van deze arealen mogelijk bleef. Teveel werd vertrouwd op de zelfwerkzaamheid van de doorsneelandbouwer en te weinig aandacht besteed aan de opbouw van een goed functionerende landbouwvoorlichtingsdienst en aan een sterke bezetting van het Landbouwproefstation, waardoor te weinig aan research kon worden verricht. Bijzonder remmende factoren waren voorts het conservatisme bij de landbouwer in het algemeen, de periodiek terugkerende droogte-perioden en de trek van het platteland naar de stad, die extra gestimuleerd werd door het voortbestaan van de discrepantie tussen stedelijk en landelijk inkomen.

Aan de hand van de reeds in de praktijk opgedane ervaring heeft het landbouwbeleid reeds sedert enkele jaren een koerswijziging in gunstige zin ondergaan. In dit verband kan onder meer worden gewezen op de goede planning en voorbereiding van diverse belangrijke agrarische projecten, het streven naar de in- 
troductie van hoogwaardige handelsgewassen, het stichten van kernondernemingen door de Overheid die als voorbeeld-bedrijven voor de kleine landbouwer dienen, het stimuleren van de oprichting van proefbedrijven, die agrarische producten verwerken, de invoering van de gecontroleerde credietbeperking en van garantieprijzen voor enkele belangrijke producten. Voorts is onder auspiciën van de Stichting Machinale Landbouw een experiment gaande met de oprichting van middenstands-rijstbouwbedrijven en de opleiding van Surinaamse boeren daarvoor: Een uitbreiding van de research, het scheppen van waarborgen dat de kernbedrijven volgens bedrijfseconomische maatstaven worden beheerd en het schenken van grotere aandacht aan de mogelijkheden, die de ondernemingslandbouw nog steeds biedt, zullen er voorts toe bijdragen dat verdere vooruitgang zal worden geboekt, waarmede uiteraard de nodige tijd zal zijn gemoeid.

Een zeer bemoedigend verschijnsel is de reeds vermelde stijging van de waarde van de agrarische uitvoer en het feit dat de toename van het aantal exportproducten grotendeels voor rekening van de agrarische sector komt. Het is vooral deze sector, die door gebruikmaking van geheel eigen grondstoffen de mogelijkheden kan scheppen voor het ontstaan van meerdere kleine en middelgrote verwerkende industrieën. Op de noodzaak van een verhoging van de exportwaarde en van een uitbreiding van het uitvoerpakket werd reeds gewezen.

Aangezien dit artikel geen ruimte laat voor een bespreking van de ontwikkeling bij de diverse cultuurgewassen, de visserij en veeteelt, zal de beschouwing over deze sector besloten worden met een korte uiteenzetting van de belangrijkste projecten, die thans in uitvoering zijn of binnenkort in uitvoering komen.

In de eerste plaats dient dan te worden genoemd het $\mathrm{zg}$. 'Bacovenplan', dat ten doel heeft de introductie van een op commerciële basis geschoeide en op export gerichte bananencultuur. Met de uitvoering van dit plan is in 1963 een aanvang gemaakt, nadat reeds enkele jaren experimentele ervaring was opgedaan met een proefaanplanting van circa 80 ha in de Prins Bernhardpolder. Blijkens een nota, opgesteld door een werkgroep van het Ministerie van Landbouw, Veeteelt en Visserij, is het streven erop gericht om in 1965 I 250 ha aan nieuw areaal in productie te hebben, zijnde het minimum areaal, waarop een regelmatige en economisch verantwoorde afvoer met bananenschepen kan worden gebaseerd. In oktober 1963 werd volgens plan de plant- 
campagne ingezet. De hiervoor benodigde polders waren in 1963 voor een groot deel voltooid. Tengevolge van de uitzonderlijke droogte, welke nagenoeg tot medio mei I964 voortduurde, werd het plantschema ongunstig beïnvloed, zodat het moment van inzet van bananenschepen verschoven moest worden tot februari 1965 .

Het bacovenplan omvat thans 5 grootbedrijven, die in 1964 en 1965 in cultuur worden gebracht, te weten twee bedrijven in Nickerie met een oppervlakte van circa $68 \mathrm{o}$ ha, een bedrijf in de Santopolder, een bedrijf in de Bomapolder en het bedrijf in de Jarikabapolder (district Saramacca). De gezamenlijke oppervlakte van laatstgenoemde drie bedrijven bedraagt 4Io ha. Voor

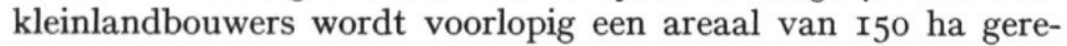
serveerd.

Van het areaal in Nickerie wordt I9o ha in cultuur gebracht door de N.V. Surbaco, een combinatie van de firma Van Hoboken, Insinger \& Co, de Nederlandse Handel Mij, de Koninklijke Nederlandsche Stoomboot Mij en de Stichting Machinale Landbouw. In de tweede helft van I964 werd na inschrijving door de Regering een verkoopcontract voor de bacoven afgesloten met United Fruit International, dat de beste verkoopvoorwaarden bood.

Yoor de bevordering van de bacovencultuur zullen vanaf I96o per ultimo rg64 ca Sf. 6 mln uit het Tienjarenplan zijn uitgegeven. De uitvoerwaarde van bacoven bedroeg in 1963 reeds Sf. 218.000 .

Een ander belangrijk project in de agrarische sector is het Combinatieplan Nickerie, dat naast de inpoldering van 4.000 ha landbouwareaal, een verbetering van de wateronttrekking uit het Nannireservoir en een verbetering van de streekontsluiting beoogt. De eerste fase van dit Combinatieplan, omvattende de hoofd-infrastructurele werken, zomede een verbetering van het Nannireservoir, werd ter financiering voorgelegd aan de E.E.G. en is inmiddels goedgekeurd. Nu ook de aanbesteding en gunning hebben plaatsgevonden, kan met de uitvoering een aanvang worden gemaakt.

Eveneens bij de E.E.G. ingediend is het Stondansie-project, dat te beschouwen is als het complement van het Combinatieplan Nickerie. Het omvat de bouw van een stuwdam in de bovenNickerierivier bij Stondansie en om verlies van bevloeiingswater te voorkomen van een schutsluis in de Arawarrarivier. 
Uitvoering van dit projekt, dat momenteel nog in studie is bij de E.E.G., geeft een permanente verbetering van de watervoorziening en voorziet het Nickeriedistrict van voldoende irrigatiewater om in niet al te droge jaren een totaal geprojecteerd landbouwareaal van 80.000 ha in cultuur te brengen. De noodzaak van deze voorzieningen is duidelijk tot uiting gekomen tijdens de extreme droogteperiode van circa juli r 963 tot en met mei I964.

Wegens het reeds gecommitteerd zijn van de resterende Tienjarenplanmiddelen kon nog geen uitvoering worden gegeven aan het zg. Centraal Commewijneplan, dat een verbetering van de waterhuishouding beoogt van het Commewijnedistrict, waarin het merendeel van de nog in exploitatie zijnde plantages is gelegen. Na gereedkoming van het Brokopondowaterkrachtwerk zal in de droge tijd de zoutgrens in de Surinamerivier zodanig worden teruggedrongen, dat toevoer van irrigatiewater uit deze rivier via een te graven hoofdirrigatieleiding en secundaire leidingen naar de te bevloeien arealen in het Commewijnedistrict mogelijk wordt. Hiermede zou de bevloeiing van rooo ha reeds in cultuur zijnde grond worden veiliggesteld, terwijl tevens 3.000 ha nog niet bebouwde grond voor landbouwdoeleinden in gebruik kan worden genomen.

Van een tweetal recente door Prof. Van Blommestein ontvouwde plannen, die het karakter van een multipurpose project hebben (o.a. opwekking van energie, levering van bevloeiingswater), te weten het Torarica-project (bouw van een beweegbare stuwdam in de Surinamerivier) en het reeds genoemde Kabaleboproject zullen de voorstudies door het Salzgitter-concern worden opgesteld.

Bosbouwkundige sector

Ofschoon Suriname voor crica $90 \%$ van zijn oppervlakte met bos is bedekt, waren de exploitatiemogelijkheden van deze natuurlijke hulpbron nog niet zolang geleden zeer beperkt. Ten eerste door de problemen, verbonden aan het transport van de kapplaats naar de afvoerwegen, waardoor slechts lintkap langs de rivieren en kreken plaatsvond. Voorts vanwege de zeer heterogene samenstelling van het tropische bos (200 soorten waarvan slechts I5 à 20 marktwaardig), waardoor de bruikbare houtopstand per hectare gering is, hetgeen de exploitatie kostbaar maakt. 
Teneinde de bosexploitatie en de houtindustrie, die tot voor de tweede Wereldoorlog van geringe betekenis waren, tot grotere ontplooiing te brengen is in de afgelopen jaren door de Dienst 's Lands Bosbeheer met succes gestreefd naar een beperking van de hierboven vermelde moeilijkheden bij de bosexploitatie. Een aantal maatregelen werd getroffen, die voor het grootste deel gefinancierd zijn uit het Tienjarenplan.

Begonnen werd met de bosinventarisatie (met behulp van luchtfoto-interpretatie, gevolgd door grondexploratie), die geconcentreerd werd op de bossen met relatief gunstige ontsluitingsmogelijkheden en met de hoogste concentratie aan marktwaardige houtsoorten. Op deze wijze werd 40.000 ha zwampbos en 275.000 ha hoog drooglandbos geïnventariseerd.

Vervolgens werden de meest geschikte terreinen ontsloten door de aanleg van bosontsluitingswegen, die aansluiten op de diepere beneden-rivieren. Momenteel is roo.ooo ha hoog drooglandbos ontsloten door $200 \mathrm{~km}$ weg en in volle exploitatie. In het zwampbos vond de ontsluiting plaats door kanalen, die met dynamiet werden 'geschoten'.

Tenslotte werd een begin gemaakt met bosverjonging door aanplant van snelgroeiende marktwaardige houtsoorten en werden enkele proefcultures ingezet, ook van buitenlandse houtsoorten. De belangrijkste proefaanplant is die van een Latijns-Amerikaanse naaldhoutsoort, de Pinus caribaea. Deze proefneming werd geëntameerd door de Dienst van 's Lands Bosbeheer in samenwerking met de Koninklijke Papierfabrieken van Gelder \& Zonen N.V. met de bedoeling om op grote schaal savannagebieden met deze houtsoort te beplanten ten behoeve van de pulpfabricage. Het was een grote teleurstelling toen Van Gelder \& Zonen na beëindiging van de experimentele fase in 1962 zich terugtrok omdat een lonende pulpfabricage niet mogelijk werd geacht. De Dienst 's Lands Bosbeheer werd geadviseerd aan het proefbedrijf een ruimer doel te geven, door de aanplant mede te bestemmen voor zaaghout en niet uitsluitend voor een pulphoutbedrijf. In 1963 werd de pinusproefaanplant verder uitgebreid met 500 ha tot 1734 ha. De gedachte aan de oprichting van een pulphoutbedrijf, zij het op een ietwat andere grondslag, is nog niet losgelaten en men poogt nog steeds buitenlandse bedrijven hiervoor te interesseren. Het Salzgitter-concern is verzocht dit vraagstuk ook nog eens in studie te nemen. 
Zowel de vermelde maatregelen van overheidswege, als de omvangrijke activiteiten van de Bruynzeel Suriname Hout Mij, hebben geleid tot een zeer bevredigende vooruitgang in de bosbouwkundige sector. Het aantal houtconcessionarissen en zagerijen nam toe, terwijl het Bruynzeel-bedrijf zich in de loop der jaren belangrijk uitbreidde en nu een zagerij, een triplex- en een spaanplatenfabriek omvat. Het volume en de waarde van de uitvoer van houtproducten nam in de periode r954-I964 constant toe. In 1963 bedroeg de uitvoerwaarde Sf. 8, 17 mln, waarvan het grootste deel voor rekening kwam van triplex, spaanplaten en gezaagd hout.

Stemt deze ontwikkeling tot tevredenheid, het betekent geenzins dat alle problemen, welke een expansie van de houtexploitatie en houtverwerkende industrie in de weg staan tot oplossing zijn gebracht. Op grond van de thans beschikbare gegevens wordt aangenomen, dat omstreeks 1985 het economisch exploiteerbare bosareaal niet meer geheel zal kunnen voorzien in de houtbehoefte. De oplossing van dit probleem is thans urgenter geworden, doordat het bosbestand in de kustvlakte grote schade heeft geleden door de hevige bos- en zwampbranden, die gewoed hebben als gevolg van de uitzonderlijke droogte van de periode augustus I963 tot medio mei I964. In het bijzonder werden de baboenbossen getroffen, die de grondstof leveren voor het belangrijkste houtuitvoerproduct, de triplex. Ook de Stuwmeergebieden gaan uiteraard voor de houtexploitatie verloren.

De bosverjonging zal derhalve op groter schaal en in versneld tempo ter hand moeten worden genomen. De daartoe beschikbare Tienjarenplanmiddelen zijn echter ontoereikend. Ook de verdere voortzetting van de bosinventarisatie en bosontsluiting dreigen te stagneren door een gebrek aan fondsen.

Een ander knelpunt bij de verdere uitbreiding van de bosexploitatie wordt gevormd door de afzetmoeilijkheden voor een vergrote productie. Het opname-vermogen van de binnenlandse markt is beperkt. Dit wordt nog geaccentueerd door het stagneren van de volkswoningbouw gedurende de laatste jaren.

De mogelijkheid voor vergroting van de export van vierkant gezaagd en rondhout in het bijzonder naar Europa is eerst aanwezig indien geconcurreerd kan worden tegen de Westafrikaanse en Z.O. Aziatische houtleveranciers. Hierbij spelen niet alleen de kostprijs in Suriname en vrachttarieven een rol, doch ook andere factoren zoals regelmatiger levering, gevarieerder gebruiksmogelijkheden, aantrekkelijker maten e.d. Ook de onbe- 
kendheid met vele Surinaamse houtsoorten werkt belemmerend.

Ten aanzien van de uitvoer van onze houtproducten naar Latijns-Amerikaanse landen en de Verenigde Staten zullen dezelfde factoren een rol spelen, doch de afzetmoeilijkheden in deze landen worden nog vergroot door protectionistische maatregelen (invoer-verboden, hoge tariefmuren). Het lijkt derhalve gewenst ook de nodige aandacht te schenken aan het elimineren van exportbelemmerende factoren en aan het handhaven van een zo laag mogelijk productiekostenpeil.

Industriële sector

Bij de opstelling van het Tienjarenplan werd van de gedachte uitgegaan dat voor een gezonde ontplooiing van de industriële productie deze zoveel mogelijk zou moeten worden overgelaten aan het particuliere initiatief. De taak van de Overheid zou zich over het algemeen moeten beperken tot het scheppen van zo gunstig mogelijke factoren voor industrievestiging. Het programma voor de ontwikkeling van een gunstig industriëel klimaat zou onder meer moeten omvatten: bedrijfsvoorlichting, het verlenen van fiscale faciliteiten, verbetering van de transportfaciliteiten, opvoering van de arbeidsproductiviteit door uitbreiding en verbetering van het vakonderwijs en speciale trainingscursussen, het aantrekken van technical assistance en de vorming van een Raad voor Industriële Ontwikkeling.

Slechts in uitzonderingsgevallen zou de Overheid actief en in directe zin moeten steunen. Ten behoeve van deze doelstelling werd uit het totale Tienjarenplanbedrag slechts Sf. $6.4 \mathrm{mln}$ uitgetrokken. Dit bedrag zou deels bestemd worden voor research ten behoeve van industriële projecten en voor de rest voor participatie in of voor kapitaalverstrekking aan industriële bedrijven waarvan de totstandkoming van essentieel belang wordt geacht en die, om welke reden dan ook, in hun kapitaalbehoefte niet op andere wijze kunnen voorzien. Ofschoon de hierboven geschetste gedachtengang op zichzelf wel aanvaardbaar is, werd echter te weinig rekening gehouden met het feit dat de industrialisatie van ontwikkelingslanden veelal moeizaam verloopt en dientengevolge meer stimulansen behoeft.

Hoewel Suriname zeker kan bogen op een aantal gunstige vestigingsfactoren, waarvan overigens enkele in de laatste jaren iets aan waarde hebben ingeboet, heeft het geen zin te verhelen dat er ook enige factoren zijn, die bepaald belemmerend werken. In de eerste plaats dient dan te worden gewezen op de geringe 
omvang van de lokale markt en op de moeilijkheden, die overwonnen moeten worden bij het opbouwen van exportmarkten, waarover reeds elders in dit artikel is uitgewijd. Voorts zijn de industriële mogelijkheden van beperkte omvang, zij het dat deze bij een voortgezette research, exploratie en industriële bedrijvigheid, op wat langere termijn, zullen toenemen.

Ten aanzien van de belangstelling van buitenlandse investeerders voor Suriname dient te worden opgemerkt, dat deze uiteraard beperkt blijft, indien zich elders gunstiger investeringsmogelijkheden voordoen, terwijl ook de betrekkelijke onbekendheid met Suriname's mogelijkheden remmend heeft gewerkt

De belangstelling van het binnenlands kapitaal ging vooral uit naar de handel en naar beleggingen in onroerend goed, en slechts in geringe mate naar investeringen in de industriële sector. Het ontstaan van eigen Surinaamse industriële bedrijven werd ook belemmerd door het feit, dat Suriname wel over tal van goede ambachtslieden beschikt, doch in onvoldoende mate over ondernemers, die leiding kunnen geven aan grotere industriële bedrijven en daarvoor over de vereiste technische 'know how' beschikken. Het behoeft geen uitleg, dat met het tot ontwikkeling komen van een krachtige eigen ondernemersstand enige tijd gemoeid is en dat aan dit facet de nodige aandacht geschonken dient te worden.

De hiervoren vermelde omstandigheden geven reeds aan dat bij de industrialisatie van Suriname enkele barrières moeten worden doorbroken. Daarbij komt nog dat gedurende de eerste jaren van de Tienjarenplanperiode van overheidswege betrekkelijk weinig maatregelen zijn getroffen tot het scheppen van een zo gunstig mogelijk industriëel klimaat. Voorts ontkomt men niet aan de indruk dat de in andere sectoren tot stand gekomen accommodatie-investeringen in het algemeen te weinig zijn afgestemd op het realiseren van aanwezig geachte industrialisatiemogelijkheden. Anders gezegd de verbetering van de infrastructuur had in meerdere gevallen een te algemeen karakter en was te weinig toegespitst op het bevorderen van de totstandkoming van concrete industrieën of bedrijven.

Deze feiten in aanmerking genomen is het niet zo verwonderlijk dat de verwachte inhaking van het particulier initiatief op de accommodatie-investeringen beneden de verwachtingen is gebleven. Toch zijn er in deze beginperiode meerdere bedrijven tot stand gekomen, die zich verder gunstig hebben ontwikkeld (bierboru- 
werij, confectiebedrijf, zuurstoffabriek, veevoederfabriek, stijlerij, e.a.). Het aantal was echter gering, zodat het werkgelegenheidsvraagstuk niet tot oplossing werd gebracht. Het nam enige jaren in beslag alvorens het industrialisatiebeleid in een meer actieve en stimulerende richting werd omgebogen.

Nadat een bescheiden aanvang was gemaakt met het beschikbaar stellen van enkele industriehallen voor de klein- en middenindustrie, kwam in I960 de Investeringsverordening tot stand, die de mogelijkheid opent tot het verlenen van fiscale en tarieffaciliteiten aan nieuwe industrieën en voor bepaalde bedrijfsuitbreidingen.

In I961 vond de oprichting plaats van de Stichting Industrie Ontwikkeling Suriname (S.I.O.S.), een semi-overheidsorgaan, dat onder meer de industriebevordering tot taak kreeg. In tegenstelling tot soortgelijke 'industrial development corporations' in sommige andere ontwikkelingslanden is de S.I.O.S. geen financieringsinstelling. Op initiatief van de Vereniging Surinaams Bedrijfsleven kwam voorts in samenwerking met het Ministerie van Economische Zaken de Stichting Surinaams Fabrikaat tot stand, die tot doel heeft het stimuleren van het gebruik van het eigen nationaal fabrikaat.

Teneinde te kunnen voorzien in de kapitaalbehoefte van industriële initiatiefnemers werd in 1963 de Nationale Ontwikkelings Bank opgericht. Van Nederlandse zijde werd ten behoeve van deze bank een bedrag van Sf. 2 miljoen beschikbaar gesteld.

Ook op het terrein van bescherming van jonge industrieën werden van overheidswege geleidelijk aan enkele maatregelen getroffen, die voornamelijk bestaan uit verhogingen van het tarief van invoerrechten. Tegen dit soort maatregelen wordt meestal als bezwaar aangevoerd dat zij inefficiency, onproductiviteit en prijsverhoging in de hand werken. Dit moge waar zijn, doch anderzijds dient er op te worden gewezen dat deze maatregelen veelal onmisbaar zijn, omdat de concurrentiepositie en groeimogelijkheden van jonge industrieën in ontwikkelingslanden doorgaans belangrijk ongunstiger zijn dan in hooggeïndustrialiseerde landen, die overigens in vele gevallen ook het protectionistisch instrument van tariefverhogingen hanteren. Bovendien kunnen de naar voren gebrachte nadelen van tariefbescherming belangrijk getemperd worden door aan deze bescherming een tijdelijk karakter te geven en door het geven van deskundige voorlichting ter verkrijging van een efficiënte bedrijfsopzet en een verlaging van de productiekosten. 
Teneinde een beter overzicht te kunnen verkrijgen van de aanwezige potentiële vestigingsmogelijkheden voor bedrijven in diverse sectoren, werd het in Nederland gevestigde Centraal Instituut voor Industrieontwikkeling (C.I.V.I.) opgedragen hiernaar een onderzoek in te stellen. Dit onderzoek, dat mede gefinancierd werd uit Tienjarenplanfondsen, is inmiddels afgesloten. Door het C.I.V.I. zijn rapporten uitgebracht over de vestigingsmogelijkheden in de verpakkings-, chemische, metaal- en houtverwerkende-industrie.

Tenslotte zijn in het kader van de Nederlandse Technische Bijstand enkele specialisten uitgezonden om van advies te dienen over de opzet en inrichting van specifieke industriële bedrijven of voor het leiden van cursussen op het terrein van personeelsscholing (bazenopleiding).

$\mathrm{Al}$ deze maatregelen en initiatieven houden een belofte in voor een succesvoller verloop van het industrialisatieproces in de toekomst. Nodig is echter een systematische 'follow-up' en het beschikbaar stellen van meer middelen en deskundigen voor een verdere uitbouw van het gevoerde industrialisatiebeleid. Voorkomen dient te worden dat de Overheid met kapitaal in nieuwe industrieën participeert, doch daarna een passieve houding aanneemt, indien de onvermijdelijke periode van kinderziekten moet worden doorgemaakt. Hiermede wil overigens niet gezegd zijn, dat het andere uiterste, te weten het optreden van de Overheid als ondernemer, als richtsnoer zal moeten dienen. Het verdient voorts aanbeveling dat het oog niet uitsluitend wordt gericht op het aantrekken van grote industrieën. De beste slagingskansen voor een vergroting van het industriële productie-apparaat liggen vermoedelijk in het vlak van het klein- en middenbedrijf en op het terrein van de uitbreidingsmogelijkheden, die reeds gevestigde industrieën bieden.

Ofschoon, zoals reeds betoogd, de industrialisatiemogelijkheden voorshands nog van tamelijk beperkte omvang zijn, ziet het er niettemin naar uit dat zich meer mogelijkheden voordoen als aanvankelijk werd aangenomen. Hierbij wordt onder meer gedacht aan de oprichting van importvervangende industrieën en verwerkingsbedrijven van agrarische producten.

Gedurende de laatste jaren zijn enkele nieuwe initiatieven gerealiseerd (o.a. margarinefabriek). Verheugend was dat het lokale initiatief daarbij op de voorgrond trad. In het stadium van proef- 
bedrijven of in studie zijn een aantal andere mogelijkheden (tapijtknoperij, vleesverwerkend bedrijf, vruchtenconservenfabriek, fabricage van vuurvaste materialen, golfcartonnagebedrijf). Vermelding verdient nog dat in I 962 op instigatie van de Raad van Nederlandse Werkgeversverbonden werd opgericht de Industriële Adviesraad voor Suriname en de Nederlandse Antillen, die zich tot taak heeft gesteld het stimuleren van de belangstelling van het Nederlandse bedrijfsleven voor de rijksdelen overzee.

In kringen van het bedrijfsleven is meerdere malen gewezen op de wenselijkheid, dat van Nederlandse zijde bepaalde faciliteiten en garanties worden verstrekt ter stimulering van Nederlandse investeringen in de rijksdelen overzee. Door een aantal landen, waaronder de Verenigde Staten, worden dergelijke faciliteiten reeds verleend met de bedoeling de particuliere investeringen in ontwikkelingslanden te bevorderen.

Doch ook op andere wijze kan Suriname's industrialisatie worden gediend. In de praktijk komt het niet zelden voor dat de oprichting van een industriëel bedrijf niet van de grond komt, omdat particuliere geïnteresseerden uit Suriname of Nederland terugschrikken voor de kosten van het voorbereidend onderzoek, van de opleiding van gequalificeerd personeel, aanloopverliezen, enz. De vraag kan dan ook worden gesteld of het geen aanbeveling verdient in de toekomst dergelijke kosten of een gedeelte daarvan te bestrijden uit de door Nederland verleende ontwikkelingshulp. Thans gebeurt dit reeds, doch te incidenteel en meestal slechts ten behoeve van een bepaald onderdeel van het betrokken industriëel project, waardoor de afronding te wensen overlaat. Het behoeft geen nader betoog dat een dergelijke vergaande hulp slechts verleend dient te worden, indien een deskundig onderzoek heeft uitgewezen dat een bepaald project na realisatie goede bestaanskansen heeft.

Overige sectoren

In de diverse sectoren van niet direct productieve aard werd grote vooruitgang geboekt.

In de verkeerssector werden bestaande wegen verbeterd en nieuwe aangelegd, terwijl een moderne luchthaven tot stand kwam. Binnenkort zal een aanvang worden gemaakt met de modernisering van de haven, welk project door de E.E.G. wordt gefinancierd. 
De accommodatie van tal van overheidsdiensten werd verbeterd, volkswoningen werden gebouwd, het aantal scholen uitgebreid, een nieuw modern ziekenhuis nadert zijn voltooiing. Dit zijn slechts enkele voorbeelden uit de reeks van vele werken, die in de afgelopen tien jaren tot stand kwamen. Voor een niet onbelangrijk deel werden zij uit het Tienjarenplan gefinancierd.

Het valt evenwel te betreuren dat gedurende de laatste jaren stagnatie is opgetreden in twee uiterst belangrijke sectoren, namelijk bij de bouw van volkswoningen en van scholen. Tendele is deze stagnatie te wijten aan een gebrek aan fondsen.Een ander knelpunt waarmede Suriname in toenemende mate wordt geconfronteerd is een tekort aan deskundigen op velerlei terrein.

De Surinaamse economie in zijn geheel overziende kan worden gezegd, dat het land nog steeds te kampen heeft met moeilijkheden die reeds vele decennia lang bestaan. Tegelijk moet worden geconstateerd, dat er op verscheidene terreinen vooruitgang wordt geboekt en dat - o.a. in rijksverband - met energie en toewijding naar oplossingen wordt gezocht.

Paramaribo, 7 november 1964 .

\section{LITERATUUR}

Centrale Bank van Suriname. Verslag over 1962 en 1963 , en andere verslagen.

De toestand van 's Lands Financiën. Ministerie van Financiën, I september 196r.

Financiële nota, behorende bij de ontwerp-begroting voor het dienstjaar 1965.

Investeren in Suriname. Vereniging Surinaams Bedrijfsleven (1959).

Onderzoek naar de mogelijkheden en exploitatie van de ijzerertsreserves in Suriname. Ned. Economisch Instituut, Rotterdam, I95I.

Ontwikkelingsplan voor Suriname. 1965. Stichting Planbureau Suriname, I964.

L. J. VRoon: Voorgeschiedenis, opzet en resultaten van het Surinaamse Tienjarenplan. Nieuwe West-Indische Gids 43, 1963, p. 25-74. 